https://doi.org/10.48009/1_iis_2006_264-267

\title{
E-BUSINESS CURRICULUM: LITERATURE REVIEW REVEALS OPPORTUNITIES AND CHALLENGES
}

\author{
Doris G. Duncan, California State University, East Bay (formerly Hayward), doris.duncan@csueastbay.edu
}

\begin{abstract}
Many dot-coms are gone, but others have prospered, indicating that e-business will exist for a long time. This paper presents a survey of literature about $e$ business and e-commerce academic programs. The past, present and future of e-business programs are discussed. Suggestions are made for research to develop a common body of knowledge needed for $e$ business and e-commerce curricula.
\end{abstract}

Keywords: E-business Curriculum, E-commerce Curriculum, MBA and MS Curriculum

\section{INTRODUCTION}

The estimates regarding the amount of business conducted electronically vary widely, but it is clear electronic business and electronic commerce have gained tremendous momentum worldwide over the past decade. Much media attention was given to the dot-com boom, but has since waned following the dot-com bust and economic downturn of the early 2000s. Despite the dot-com bust, it is clear many successful electronic businesses, e.g., eBay and Amazon, will evolve and thrive for many years. Despite the dot-com bust and some off-shoring, technology-oriented careers continue to rise in the USA. The U.S. Bureau of Labor Statistics forecasts job growth in all computing specialties of $20 \%-50 \%$ by 2012 with the exception of computer operators (decline) and programmers (flat) [5].

It is not surprising that the development of e-business (EB) courses, concentrations and degree programs has followed the economic trends. Since the first ebusiness concentration was instituted at Vanderbilt University in 1995, a variety of courses and programs have ensued, especially during the technology boom years during the late 1990s [13]. Since 2000-01, many technology-oriented programs have experienced substantial enrollment declines. In computer science, the numbers of incoming freshmen fell by $60 \%$ between 2000 and 2004 [5]. Other technology programs have enrollment declines of at least $40 \%$. Meanwhile enrollments in most business programs have held steady, or in a few cases, declined slightly [1].
Serious introspection is needed in the academic community regarding how to best serve the business and technology community and future students. In particular, this paper will explore the possible need to identify leading e-business programs that could become the basis for a standardized e-business curriculum. Indeed, it may be time for a paradigm shift in business and technology education.

This research paper looks at one aspect of business and technology education, namely e-business offerings: their past, present, and future directions based on a survey of the literature. Since the term "ecommerce" is often used interchangeably with "ebusiness," this research will include e-commerce. Technically, e-commerce involves exchanges of money over the internet whereas e-business adds other business activities, for example, collaboration with business partners. Thus, e-commerce is really a subset of e-business.

\section{METHODOLOGY}

The author conducted a comprehensive search of literature by reviewing the following resources from about the year 2000 to present:

1) Issues in Information Systems, annual serial publication of IACIS

2) Journal of Computer Information Systems, published by IACIS

3) EDSIG/ Information Systems Education Conference (ISECON) proceedings

4) Journal of Information Systems Education, published by Association of Information Technology Professionals - Special Interest Group in Education (AITP/EDSIG)

5) Information Systems Education Journal, published by AITP/EDSIG

6) Journal of Informatics Education, published by the International Academy of Informatics Management (IAIM)

7) IAIM conference proceedings 
8) InSite conference proceedings, published by Informing Science

9) Journal of Information Technology Education, published by Informing Science

10) Journal of Strategic E-commerce, published by Allied Academies, year 2005

11) Academy of Information and Management Science Journal, published by Allied Academies, year 1999 onward

12) Review of Association of Business Education (ABE) Conference Proceedings

13) Association of Computing Machinery, Special Interest Group in Education (ACM-SIGCSE) conference proceedings

14) Review of ACM Model Curricula 1972 - 2006, undergraduate and graduate

15) Review of Information Resource Management Association (IRMA) model curriculum 2000, 2003 draft - undergraduate only

16) Review of Organizational Systems Research Association (OSRA) OEIS model curriculum undergraduate only, year 2003.

The most comprehensive research appears to have been done around year 2000 near the peak of the dotcom boom. Many of the references listed at the end of this paper are from this time. Some of the most comprehensive research published has been identified and is discussed and synthesized in the next section.

\section{FINDINGS}

Surveys of e-business programs show the programs are as varied as where they are housed. O'Hara [13] found that some schools offered both an undergraduate and graduate degree program in EB. Many schools offered only one course. Often the EB programs were housed in the department of information systems and sometimes in marketing, general business, management or accounting. O'Hara [13] surveyed 122 programs in e-business and ecommerce and found that many more schools offered degree programs at the graduate level than undergraduate level. MS degrees in e-commerce were offered by 15 schools; 6 schools offered an MS in other areas with an e-business concentration; 2 schools offering an EB concentration had degree programs in management. The degree program at 4 other schools was in information systems. An EB concentration within the MBA degree program was most common, with 29 schools offering this. Some MBA programs were more management oriented and others were more technical. At the undergraduate level, O'Hara identified 4 schools that offered an EB degree and 3 schools that offered a concentration in EB within another major area. The major areas were information systems, general business and marketing. An EB minor was offered by 2 schools.

Furthermore, O'Hara [13] found that many schools offered EB courses if not programs. The majority, 48 schools, offered only one EB course although this may be changing. She found 13 schools that offered two EB courses and 3 schools that offered 3 courses. Of the schools offering only one course, 35 of them offered this course in the area of information systems. Other areas where the course was housed included marketing (2), management (3), accounting (1) and general business (5). Of the schools offering just one course, 22 of them did so at the graduate level while $21 \mathrm{did}$ so at the undergraduate level. Some schools offered minors or certificate programs in e-business. O'Hara concluded, "In light of the critical shortage of IS faculty at many institutions, is it wise to begin a new program that further taxes the staff?" Of course, this was before enrollments in most IS programs plummeted [13].

Novitski [11] conducted a study of MBA and MS programs in e-business and also found many of the programs were housed in a variety of schools and programs: in business schools, engineering schools, computer science programs and schools of applied technology and arts/sciences. Novitski also determined that many EB programs were the result of faculty skills available and requests for specific skills from organizations (e.g., recruiting firms) rather than a logical integrated approach. Novitski based his findings on a study of three groups of graduate schools in North America, Europe and Hong Kong. A pool of 79 programs was selected from Association to Advance Collegiate Schools of Business (AACSB) schools, certified ecommerce consultants schools and techno-MBA programs listed in Computerworld.

Additional findings by Novitski [11] included the following:

- For the MBA EB programs the number of required courses ranged between 3 and 5 (mean $=3.7$ ). For the MS EB programs, the number of required courses ranged between 3 and 7 (mean $=5.7$ ). 
- The number of unique courses was about 100; the top 25 schools had the least breadth and number of course offerings.

- MBA schools offered a low number of courses for the MBA but a large number of courses for the MS programs.

- Breadth of offerings showed considerable variation in what materials were presented to students in the same concentration in different schools.

- The most commonly offered EB courses in MBA and MS programs accredited by the AACSB are summarized in Table 1. Percentages reflect how commonly the courses were listed in programs. Thus, the most commonly offered MBA EB courses were: 1) e-business marketing, 2) ebusiness technology, 3) introduction to e-business, and 4) data mining/data bases. The most commonly offered MS EB courses were: 1) e-business marketing, 2) e-business technology, 3) security, and 4) e-business programming.

Table 1. Comparison of Most Commonly Listed Courses: MBA and MS Programs

\begin{tabular}{|l|c|c|}
\hline Course/Topic & MBA & MS \\
\hline Intro to E-business & $51 \%$ & $75 \%$ \\
\hline E-business Technology & $72 \%$ & $84 \%$ \\
\hline E-business Marketing & $82 \%$ & \\
\hline Data Mining/data bases & $39 \%$ & \\
\hline Legal Issues and Ethics & & \\
\hline E-business Strategy & & $53 \%$ \\
\hline Supply Chain Management & & $53 \%$ \\
\hline Security & & $47 \%$ \\
\hline E-business Programming & & $32 \%$ \\
\hline Capstone Project/practicum & & \\
\hline Law and Regulations & & \\
\hline Strategy & & \\
\hline E-business Management & & \\
\hline Systems Analysis and Design & & \\
\hline
\end{tabular}

In his concluding remarks, Novitski [11] stated, "Material presented in e-business concentrations often seems more linked to the base discipline than to the issues and concerns of e-business. The problem appears to be widespread."

In a separate study of e-business education, Novitski [12] focused on what should an e-business/commerce program present as key elements. He pointed out that the most commonly offered course in MBA EB concentrations was e-business marketing, in over $50 \%$ of the programs. In MS EB programs, the two most frequently offered courses were e-business marketing and e-business technology. Lee, Chen and Barnes [9] in a survey of faculty also found the two most popular EB subject offerings were internet [EB] marketing and internet [EB] technology. One must ask why introduction to e-business was not among the two most frequently offered classes. Eventually ebusiness programs may develop a standard core of knowledge, but it will be up to the faculty to make this happen. If this fails to happen, the EB field may not become established as an independent area of study.

Durlabhji and Fusilier [6], similar to Novitski, found the most common type of e-business program was the MBA EB concentration. This study was based on a study of 67 graduate programs in North America available in the year 2000. The authors noted that non-technical courses prevailed, possibly because this is what faculty members were prepared to teach. Of course, "hands-on" courses also required lab resources. At the time of the study, students were stampeding registration lines to enroll in e-business programs at schools like the University of Chicago and MIT Sloan School of Management. This was around the time companies were paying signing bonuses. For example, Dell Computer paid over $\$ 22,600$ on average to MIT e-commerce graduates when they accepted a job offer from Dell [10].

A review of model curricula for information systems, computer science and related fields revealed that one e-business course is usually included [2, 3, 4, 8, 7]. 


\section{CONCLUSION}

Many dot-coms have disappeared but other ebusinesses, such as EBay and Amazon, have grown and prospered over the past decade, suggesting that ebusiness will be around for a long time. E-business programs of study so far are fragmented and too often designed around the skills of the faculty and stakeholders instead of what is truly needed for the new economy. EB programs range from a single course offering to MS degree programs, the MBA with an EB concentration being the most commonly offered. Home departments are also varied, ranging from business programs in information systems, marketing, management, general business or accounting to computer science and schools of engineering, technology and sometimes arts/sciences. Clearly, a much-needed consensus about what issues should be covered in the core EB program is lacking.

Areas for future research to develop a better understanding of what exists and what is needed in ebusiness and e-commerce curriculum development include 1) a survey of industry regarding e-business and technology needs, 2) a survey of program heads who oversee selected programs in e-business and information technology and 3) a survey of college students or recent graduates.

\section{REFERENCES}

1. Chabrow, E. (2004). By the book. Information Week. August 16, 38-46.

2. Cohen, Eli, editor, (2000). Curriculum Model 2000 of the Information Resource Management Association and the Data Administration Managers Association. Accessed most recently May 28, 2006: http://gise.org/IRMA-DAMA2000.pdf.

3. Cohen, E. (2003). Curriculum Model 2003 of the Information Resource Management Association and the Data Management Association International. Unpublished report draft.

4. Daniels, K. \& Feather-Gannon, S. (2003). The development and revision of a model curriculum in organizational and end-user information systems. Proceedings of the Information Systems
Education Conference (ISECON). San Diego, CA USA, 1-13.

5. Denning, P. J. \& McGettrick, A. (2005). Recentering computer science. Communications of the ACM, 48(11), 15-19.

6. Durlabhji, S. \& Fusilier, M.R. (2002). Ferment in business education: e-commerce master's programs. Journal of Education for Business,. 77(3), 169-176.

7. Gorgone, J. T., Gray, P., Feinstein, D., Casper, G., Luftman, J. N., Stohr, E. A., Valacich, J., \& Wigand, R. (2000). MSIS 2000: Model curriculum and guidelines for graduate degree programs in information systems. Communications of the Association for Information Systems, 3(1), 1-56.

8. Gorgone, J. T., Topi, H., Feinstein, D. L., Valecich, J., Longenecker Jr., Herbert, D., \& Gordon B. (2002). IS2002-Final report of the undergraduate information systems model curriculum. Proceedings of the $17^{\text {th }}$ Annual Conference of the International Academy for Information Management. Barcelona Spain, 326333.

9. Lee, H., Chen, K. L. \& Barnes, C. C. (2001). An investigation of e-commerce curriculums in national colleges of business. Issues in IS 2001. 213-220.

10. Lord, M. (2000). Suddenly, e-commerce is the hot new specialty. U.S. News \& World Report. April 10, 62-64.

11. Novitzki, J. E. (2002a). E-business education: A comparison of graduate programs and curricula. InSITE Conference Proceedings, Cork Ireland, 1187-1196.

12. Novitzki, J. E. (2002b). e-business education: A quantitative review of program attributes and offerings. Proceedings of the $17^{\text {th }}$ Annual Conference of the International Academy for Information Management. Barcelona Spain, 3539.

13. O'Hara, M. T. (2000). A survey of electronic business and electronic commerce degree programs. Proceedings of the $15^{\text {th }}$ Conference of the International Academy for Information Management, Brisbane Australia, 60-69. 